\title{
THE EFFECTIVENESS OF HAJJ RITUAL GUIDANCE SERVICES BY THE MINISTRY OF RELIGIOUS AFFAIRS ON EASTERN INDONESIA
}

\author{
EFEKTIFITAS PELAYANAN BIMBINGAN MANASIK HAJI \\ OLEH KEMENTERIAN AGAMA DI KAWASAN TIMUR INDONESIA
}

\author{
Sitti Arafah \\ Balai Penelitian dan Pengembangan Agama Makassar \\ Jl. AP. Pettarani. No. 72 Makassar \\ Email: sittiarafah0702@gmail.com
}

Naskah diterima tanggal 8 April 2020, Naskah direvisi tanggal 26 Mei 2020, Naskah disetujui tanggal 9 Juni 2020

\begin{abstract}
The main goal to pilgrimage is to achieve the predicate haji mabrur (a pilgrim that completely undergoes the rituals and principles) through its rituals. The Ministry of Religion, specifically the Office of Religious Affairs as the vanguard, has duties and functions one of which is to provide Hajj ritual guidance services to prospective pilgrims. This study aimed to determine the level of effectiveness of Haij ritual guidance services at the Ministry of Religion in Eastern Indonesia, by measuring four dimensions broken down into six indicators namely managerial (committee and supervisor), management (planning and implementation), programs (ritual guidance material) hajj), and facilities and infrastructure. This study used quantitative methods, by distributing questionnaires to 900 respondents in 14 cities in Eastern Indonesia, using the Slovin formula with an estimated error of 0.03. The selection of cities was carried out randomly including Balikpapan, Tarakan, Makassar, Palopo, Parepare, Ternate, Tidore, Gorontalo, Kotamubagu, Kendari, Bau-Bau, Ambon, Tual, and Jayapura. Quantitative data analysis used the liker scale (1-4), and the data were analyzed descriptively. The results showed that the effectiveness of the pilgrimage guidance services at the Ministry of Religion in Eastern Indonesia with a total index was; 3.55 or categorized as "very effective", which were committee indicators (3.54) supervisors (3.47), (3.27) entire planning (3.32), services (3.26), program indicators / guidance materials (3.37), and indicators of facilities and infrastructure (3.34). Therefore, in an effort to improve services Hajj ritual services at the Ministry of Religion need to be conducted sustainably through practices for all prospective pilgrims. In addition, The instructor need to be trained better to improve in the mastery of the Hajj rituals, as well as the maintenance of regulations and facilities and infrastructure required in the Hajj ritual services.
\end{abstract}

Keywords: effectiveness, guidance, hajj rituals, indicators

\begin{abstract}
Abstrak
Tujuan utama dalam pelaksanaan ibadah haji yakni meraih predikat haji mabrur melalui ritualritualnya. Kementerian Agama, secara khusus Kantor Urusan Agama sebagai garda terdepan, dimana salah satu tugas dan fungsinya adalah memberikan pelayanan bimbingan manasik haji pada calon jemaah haji. Penelitian ini bertujuan untuk mengetahui tingkat efektivitas pelayanan bimbingan manasik haji pada Kementerian Agama di Kawasan Timur Indonesia, dengan mengukur empat dimensi yang dijabarkan ke dalam enam indikator yakni dimensi pengelola (panitia dan pembimbing), pengelolaan (perencanaan dan pelaksanaan), program (materi bimbingan manasik haji) dan sarana dan prasarana. Penelitian ini menggunakan metode kuantitatif, dengan menyebarkan kuesioner sebanyak 900 responden pada 14 kota di Kawasan Timur Indonesia, menggunakan rumus Slovin dengan galat duga 0.03. Pemilihan kota dilakukan secara acak meliputi Balikpapan, Tarakan, Makassar, Palopo, Parepare, Ternate, Tidore, Gorontalo, Kotamubagu, Kendari, Bau-Bau, Ambon, Tual dan Jayapura. Analisis data kuantitatif dengan menggunakan skala likert (1-4), data dianalisis secara deskriptif. Hasil penelitian menunjukkan, bahwa efektivitas pelayanan bimbingan manasik haji pada Kementerian Agama di Kawasan Timur Indonesia, dengan indeks total yakni; 3.55 atau terkategori "sangat efektif", yakni indikator panitia (3.54) pembimbing (3.47), (3.27) meliputi perencanaan (3.32), pelayanan (3.26), indikator program/materi bimbingan (3.37) dan indikator sarana dan prasarana (3.34). Dengan demikian, dalam upaya peningkatan pelayanan manasik haji pada Kementerian Agama perlu dilakukan secara berkesinambungan melalui
\end{abstract}


kegiatan pra manasik bagi seluruh calon jemaah haji. Di samping itu perlunya peningkatan kapasitas penyuluh dalam penguasaan materi manasik haji, serta adanya maintanance dari sisi regulasi maupun sarana dan prasarana yang dibutuhkan dalam pelayanan manasik haji.

Kata Kunci: efektivitas, bimbingan, manasik haji, indikator

\section{PENDAHULUAN}

$\mathrm{H}$ ajj or internationally called pilgrimage is a total transformation (thawaf), consistency and persistence of the struggle $\left(s a^{\prime} i\right)$, an evaluation of the principles and steps made and visualized the fut ure through the principles of thinking and natural steps (wukuf). It is also a training in physical preparation and mentality in facing future challenges (lontar jamrah) (Nurul, 2014: 4)

A perfection to perform the pilgrimage is every Muslim's dream, even though in reality to get perfection is not easy. The reality on the ground shows that Muslims have a different level of understanding of knowledge in the implementation of the Hajj. Besides, they are worried about various things (being lost, unable to speak Arabic, afraid of being lost from the team or others) (Widyarini, 2013).

The main objective in pilgrimage is to be Haji Mabrur through its rituals, in addition to a series of other activities. The implementation of the hajj requires a complex and interrelated governance and system of worship, so organizing the pilgrimage was then regulated in law and the implementation was carried out by the government and the community. The first law governing the pilgrimage is Law Number 17 of 1999, then perfected by Law Number 13 of 2008, concerning the Implementation of Hajj (Fahham. Achmad Muchaddam, 2015). Article 1 of Law No. 13/2008 reads "that the government is obliged to provide guidance, service, and protection by providing administrative services, pilgrimage guidance, transportation, accommodation and things needed by pilgrims to fulfill obligations in accordance with Islamic provisions. (Law and Human Rights, 2008).

Hajj is one of the icons of the Ministry of Religion. For some people the success of the Ministry of Religion's performance is often only measured to what extent the Ministry of Religion successfully organizes the annual worship management. This perspective is certainly neither right nor wrong, because indeed the Ministry of Religion has the task of development in the field of religion, which has 5 priority agendas as set out in the 2015-2019 RPJMN and point (4) reads the improvement in the quality of the implementation of the pilgrimage (Suparta Munzeir, 2014).

Therefore, in the implementation of the pilgrimage, the Ministry of Religion has issued various regulations in order to improve the quality of its services. In the context of increasing the capacity and readiness of prospective pilgrims, the government is continuously making efforts to improve services, especially in the guidance of Hajj rituals. The provision of prospective pilgrims with knowledge and attitude and skills is the task of the government under the coordination of the Ministry of Religion, as an institution that has the authority and is obliged to provide services in the guidance of hajj rituals as stipulated in the Law, Regulation of the Minister of Religion, and Circular related to the implementation of hajj.

To respond the needs of users or prospective pilgrims to meet the needs of Hajj Manasik guidance services, various regulations were issued. These include Regulation of the Minister of Religion Number 14 of 2012 concerning Organizing Regular Hajj (Minister of Religion, 2012) and Regulation of the Minister of Religion Number 9 of 2014, concerning Guidance on Hajj Rituals for Regular Pilgrims by the District Religious Affairs Office (Minister of Religion, 2014) and subsequently relegated in the Decree of the Director General of Hajj and Umrah Management Number 161 of 2017 concerning "Guidelines for the Implementation of Hajj Ritual Guidance by 
the Office of the Ministry of Religion of Regencies / Cities and District Religion Affairs Office (Director General of Hajj and Umrah Implementation, 2017), amended into a Circular of the Director General of Hajj and Umrah Implementation Number. B-15,006 / DJ / II.I / 1 / Hj.01 / 04/2018 concerning Implementation of District/City Level Pilgrimage Guidance and District Religious Affairs Office and Team Procurement and Team Leader (Director General of Hajj and Umrah Management, 2018).

A Ministry of Religion, which is in charge in religious fields to improve the quality of understanding and practice of community religious teachings in order to improve the quality of religious life, must improve the quality of the organization of hajj (Arafah, 2017: 228).

Related to the implementation of the pilgrimage to meet the needs of pilgrimage guidance services to prospective pilgrims, the Ministry of Religion is given the delegation of duties and responsibilities to each Ministry of Religion at the City / Regency level. Services for the implementation of hajj in each city/regency in terms of guidance on hajj rituals are conducted by Ministry of Religion in cities and the Offices of Religious Affairs.

The Office of Religious Affairs (KUA) as a technical implementation unit is the technical implementing unit of the Ministry of Religion, and is operationally fostered by the Head of the Office of the Ministry of Religion at the City / Regency level, domiciled in each sub-district. The Office of Religious Affairs are as the frontline for the Ministry of Religion in providing maximum service and guidance to the public. As in Regulation of the Minister of Religion Number. 34 of 2016, concerning the Organization and Work Procedures of the Office of Religious Affairs, in article 3 paragraph 2, in addition to carrying out the functions as referred to in paragraph (1) district KUA can carry out the function of Hajj ritual guidance services for regular pilgrims (Minister of Religion, 2016).

Some Hajj researches are mainly on issues of satisfaction. Indonesia Hajj Congregation Satisfaction Index Survey, conducted by BPS from 2010 to 2019, resulted in index of 85.91 or categorized as "very satisfying" (Official Gazette of Statistics No.82 / 10.Th. XXII, 17 October 2019). Other studies that have been conducted previously include research conducted by the Center for Religious Life Research and Development Agency of the Ministry of Religion (2014), showing that the prospective pilgrims' perceptions about the guidance and services of KBIH in Indonesia, and Saudi Arabia with the results of the pilgrimage assessment of guidance Hajj rituals and services in Indonesia are quite good but not so good for religious guidance in Saudi Arabia. (Koeswinarno, 2014).

Makassar Religious Research and Development Center has conducted research of the Hajj with its various problems such as "Hajj in the Public Spotlight Volume 1 (2013) and volume 2 (2014). The study results indicate that the pilgrimage satisfaction index is in the satisfying category (Kawu, 2013 and 2014). Furthermore, the "Hajj Pilgrimage Socio-Cultural Monograph" (2017) concludes that the socio-cultural setting of the pilgrimage is sufficient to influence the prospective pilgrims in following the implementation of the pilgrimage conducted by the Ministry of Religion. Their educational background and occupation have the most prominent influence. From the education side, most of the prospective pilgrims only had elementary school education and did not even attend school, and the dominant occupations were housewives and farming. These two things affect the implementation of Hajj rituals because they were difficult in understanding the material delivered by the supervisor through the media, such as power points (Syamsurijal, 2017)

This study raises the issue of how the effectiveness of the Hajj Rituals guidance service by the Ministry of Religion/Office of Religious Affairs in Eastern Indonesia is. The objective of this study is to determine the effectiveness of the Hajj Ritual guidance services conducted by the Ministry of Religion in Eastern Indonesia.

\section{LITERATURE REVIEW}

\section{Effectiveness}

Effectiveness is basically related to the achievement of management goals linked to work results and targets that have been set. 
Goodall and Culhane, Effectiveness is a condition that holds an understanding of the expected consequences. In line with this, Prawirosentono states that Effectiveness is very much related to the problem of how to achieve goals/results, how the level of functional power of an organization's components is and how to achieve the level of satisfaction (Muin, 2014, 367-368).

The effectiveness in this study is that there are efforts made by the Ministry of Religion and the Office of Religious Affairs to increase knowledge and underst anding of each prospective pilgrim as a user toward principles, obligatory pilgrimage, or prohibited things during ihram after following the guidance of Hajj rituals.

\section{Public Services and Services of Ministry of Religion}

Services are essentially work done for others. Some interpret it as an activity to help others. In the context, goods and services are differentiated. Therefore, service is a form of activity provided by individuals, groups, organizations and government institutions to the users to provide assistance or satisfaction in its vision (Arafah, 2017: 229).

The service in this study is an activity carried out by the Ministry of Religion related to the ritual guidance services provided by managers at the City / Regency Ministry of Religious Affairs as well as at the Office of Religious Affairs to meet the needs and increase the understanding of prospective pilgrims to the Hajj ritual guidance.

It has been regulated in Law Number 25 of 2009, Chapter I articles 1 and 2, as follows:

"Activities or series of activities in order to meet service needs are in accordance with statutory regulations for every citizen and resident for goods, services, and / or administrative services provided by public service providers."

Furthermore, those who carry out public services are state agencies, as explained in article 2, namely:

"Public service providers, hereinafter referred to as Organizers, are all state-run institutions, corporations, independent institutions formed under the law for public service activities, and other legal entities formed solely for public service activities." (Indonesia, 2009).
Decree of the Minister of Administrative Reforms Number 63 of 2003 concerning General Guidelines for the Implementation of Public Services, in the public service principle, includes first, transparency : Public services must be open, easy and accessible to all parties who need and are provided adequately and easily understood. Second, accountability in public services must be accounted for in accordance with statutory provisions. Third is conditional, in accordance with the conditions and capabilities of service providers and recipients while adhering to the principles of efficiency and effectiveness. Fourth is participatory, encouraging community participation in the delivery of public services by taking into account the aspirations, needs and expectations of the community. Fifth is equal rights, non-discriminatory in the sense of not distinguishing ethnicity, race, religion, class, gender, economic status, and Sixth is balance of rights and obligations. The giver and recipient of public services must fulfill the rights and obligations of each party (Minister of Administrative and Bureaucracy Reform, 2003)

\section{Guidance}

Guidance may mean: (1) directing, (2) driving, (3) managing, and (4) driving. In the view of Islam, as stated by Thohari Munawar. it is a process of providing assistance to individuals so that their religious life is always in harmony with the provisions and instructions of God in order to achieve happiness in the world and hereafter. (Pajala, 2005 , p. 90). Guidance in this study is an attempt to equip knowledge for prospective pilgrims in order to increase understanding in the implementation of the pilgrimage, in theory and practice.

\section{Hajj/Pilgrimage Rituals}

Etymologically manasik is derived from the Arabic word nusuk that means worship to God (Yunus, 1994). In Indonesia Dictionary manasik means worship (Ministry of National Education, 2003). Hajj rituals are defined as training in the implementation of 
the pilgrimage given to prospective pilgrims, conducted by the Ministry of Religion and the Hajj Guidance Group, which is guided by a supervisor.

Therefore, Hajj ritual services are those to provide prospective pilgrims about the concept of knowledge and insights related to the pilgrimage in theory, accompanied by practices or simulations using props such as miniature Ka'bah, ihram clothes, wukuf, sai, tahalul and so on.

\section{RESEARCH METHODS}

This study used a quantitative approach. The quantitative approach is analyzed by numbers and is basically carried out systematically, controlled, empirically and critically. Arikunto explains that research using survey methods is carried out by collecting data from a number of samples / populations to represent the entire population (Suharsimi, 2007, p. 94). The data collection techniques in this study was through questionnaires.

Sampling was done randomly with the assumption that the population was homogeneous based on: (1) research locations in the city (2) the use of the same technical guidelines and operational guidelines (rules). The city population as a whole in the Eastern Region of Indonesia was 21 cities, after being randomly selected. Fourteen cities were chosen as locations for distributing questionnaires, involving 6 enumerators (data collectors).

The respondents who were sampled in this study were 900 people based on the method of determining the sample using the Slovin technique with an estimated error of 0.03 (3\%). Thus, the number of samples distributed in 14 cities in Eastern Indonesia included: Balikpapan (103), Tarakan (30), Parepare (24), Palopo (21), Kendari (121), Bau-Bau (36), Ternate ( 54), Tidore (23), Ambon (70), Tual (20), Gorontalo (84), Kotamubagu (24), Jayapura (66), and Makassar (224).

Data processing and analysis were carried out based on a Likert scale, scoring each choice of answers from respondents with scores 1-4 namely disagree (1), less agree (2), agree (3) and strongly agree (4). With categorization: 1.00-1.75 (ineffective), 1.76-
2.50 (less effective), 2.51-3.25 (effective) and 3.26-4.00 (very effective). Some of the steps carried out were coding, entry and tabulation data entry, quantitative data analysis and crosstab through SPSS.

\section{DISCUSSION}

\section{Manasik Guidance Attended}

Dealing with guidance attended, 900 respondents answered : as many as 592 people attended $(65.8 \%)$ Pramanasik activities, while 308 (34.2\%)did not. In Guidance of KUA, as many as 884 people $(98.6 \%)$ participated, and 16 people (1.4\%) did not. In guidance to the Ministry of Religion, as many as 875 respondents $(97.2 \%)$ participated, and $25(2.8 \%)$ did not . Guidance on $\mathrm{KBIH}$ as many as 206 people $(22.9 \%)$ participated, and 694 people $(77.1 \%)$ did not. Finally in guidance on spiritual teachers / religious teachers, as many as 123 people $(13.7 \%)$ attended it, while 777 (86.3\%) did not.

\section{Respondents' Identity}

In terms of gender, 435 people $(48.3 \%)$ were males and 465 people $(51.6 \%)$ were females, but 1 person was not identified. In terms of age, the dominant respondents were at age: 7 people $(0.8 \%)$ were $20-30,38$ people $(4.2 \%)$ were $31-40,192$ people $(21.3 \%$ ) were $41-50,422$ people (46.9\%) were 51-60 , 187 people $(20.9 \%)$ were $61-70,39$ people $(4.3 \%)$ were $71-80,12$ people $(1.3 \%)$ were 81 90, and 1 person $(0.1 \%)$ was $91-100$.

According to the education, $7(0.8 \%)$ did not attend schools, 4 people $(0.4 \%)$ did not graduate from elementary/MI percent, 103 people (11.4\%) graduated elementary school, 19 people ( $2.1 \%$ ) did not complete junior high school / Mts, 86 people $(9.6 \%)$ graduated from junior high school, $181(20.1 \%)$ did not graduate from senior high school, 318 people (35.3\%) percent graduated from senior high school, 13 people $(1.4 \%)$ graduated from DID3, 141 people $(15.7 \%)$ graduated from undergraduate/ $\mathrm{S} 1, \quad, 25$ people $(2.8 \%)$ gradatuated from master degree/S2, 2 people $(0.2 \%)$ graduated from doctoral degree/S3, and 1 person $(0.1 \%)$ did not mention his/her educational identity.

Dealing with occupation, most of the respondents, 293 people (32.6\%) were traders, 
while 173 people (19.6\%) were civil servants/employees, 51 people $(5.7 \%)$ were farmers, 16 people $(1.6 \%)$ were fishermen, 209 people ( $23.2 \%)$ were self-employed, 139 people $(15.4 \%)$ chose others, and 19 people (2.1\%) did not answer it. About whether ever to pilgrimage or not, 873 people $(97.0 \%)$ had done it once, 16 people $(1.8 \%)$ percent had done it twice, and $11(1.2 \%)$ done it 3 times.

The Effectiveness of Hajj Ritual Guidance Services in Eastern Indonesia

\section{Overall Index of Hajj Ritual Guidance Services in Eastern Indonesia}

Table. 1:Overall Index of Hajj Ritual Guidance Services in Eastern Indonesia

\begin{tabular}{|c|c|c|c|c|}
\hline No & Dimension & Indicator & $\begin{array}{l}\text { Ind- } \\
\text { ex }\end{array}$ & Information \\
\hline 1 & Manager & $\begin{array}{l}\text { Committee } \\
\text { Service } \\
\text { Mentor } \\
\text { Service }\end{array}$ & $\begin{array}{l}3.54 \\
3.43\end{array}$ & $\begin{array}{l}\text { Very } \\
\text { Effective } \\
\text { Very } \\
\text { Effective }\end{array}$ \\
\hline 2 & Management & $\begin{array}{l}\text { Planning } \\
\text { Service } \\
\text { Implement } \\
\text { Service }\end{array}$ & $\begin{array}{l}3.32 \\
3.26\end{array}$ & $\begin{array}{l}\text { Very } \\
\text { Effective } \\
\text { Very } \\
\text { Effective }\end{array}$ \\
\hline 3 & Program & $\begin{array}{l}\text { Guidance } \\
\text { Material }\end{array}$ & 3.37 & $\begin{array}{l}\text { Very } \\
\text { Effective }\end{array}$ \\
\hline 4 & $\begin{array}{l}\text { Facilities and } \\
\text { infrastructure }\end{array}$ & $\begin{array}{l}\text { Facilities and } \\
\text { infrastructure }\end{array}$ & 3.34 & $\begin{array}{l}\text { Very } \\
\text { Effective }\end{array}$ \\
\hline Tot & al Index & & 3.55 & $\begin{array}{l}\text { Very } \\
\text { Effective }\end{array}$ \\
\hline
\end{tabular}

The data above shows that the entire indicator measured obtains the index value categorized as "Very Effective". In the indicator, implementation service has the lowest index of 3.26, while committee service has the highest index of 3.54.

\section{Hajj Ritual Guidance Service Index based on Indicators Manager}

Table. 2: Index to Committee Service Indicator

\begin{tabular}{|c|c|c|c|}
\hline No & Statement & Index & Category \\
\hline 1 & $\begin{array}{l}\text { Committee always } \\
\text { helps participants }\end{array}$ & 3.41 & $\begin{array}{l}\text { Very } \\
\text { Effective }\end{array}$ \\
\hline 2 & Committee is friendly & 3.38 & $\begin{array}{l}\text { Very } \\
\text { Effective }\end{array}$ \\
\hline \multirow[t]{2}{*}{3} & $\begin{array}{l}\text { Committee concerns } \\
\text { with participants' } \\
\text { needs. }\end{array}$ & 3.35 & $\begin{array}{l}\text { Very } \\
\text { Effective }\end{array}$ \\
\hline & Total Index & 3.54 & $\begin{array}{l}\text { Very } \\
\text { Effective }\end{array}$ \\
\hline
\end{tabular}

196 | Jurnal “Al-Qalam” Volume 26 Nomor 1 Juni 2020
The data above shows that the committee's services to prospective pilgrims are done well. They assist every need of prospective pilgrims with hospitality, indicated by a very effective index of 3.54 .

\begin{tabular}{|c|c|c|c|}
\hline No & Statement & Index & Category \\
\hline 1 & $\begin{array}{l}\text { Material delivery is } \\
\text { good and not } \\
\text { monotonous }\end{array}$ & 3.48 & Very effective \\
\hline 2 & Patient and painstaking & 3.42 & Very effective \\
\hline 3 & $\begin{array}{l}\text { Give participants } \\
\text { opportunity to ask }\end{array}$ & 3.47 & Very effective \\
\hline 4 & Use a varied method & 3.43 & Very effective \\
\hline 5 & $\begin{array}{l}\text { Material delivery on } \\
\text { schedule }\end{array}$ & 3.35 & Very effective \\
\hline \multirow[t]{2}{*}{6} & $\begin{array}{l}\text { Answer clearly and } \\
\text { satisfyingly }\end{array}$ & 3.42 & Very effective \\
\hline & Total Index & 3.43 & Very effective \\
\hline
\end{tabular}

A method by every supervisor is one of the aspects to succeed in the implementation of the Hajj ritual guidance. The different bcthat will be found in each supervisor must have the ability or expertise in an effort to improve the understanding of the rituals of Hajj to every prospective pilgrims given that each prospective pilgrim has various backgrounds in terms of education, work, understanding of religion, age, culture or habits, and characters.

All of the six statements submitted to respondents were very effective in the index. This shows that the guide involved in the guidance of Hajj rituals provided services to prospective pilgrims well and communicatively. Besides, and ability to deal with prospective pilgrims psychologically from various traits and characters was good with a variety of methods together with practice, so the prospective pilgrims did not feel bored.

Thus, the supervisors implemented several types of methods in the delivery of material that could improve the understanding of Hajj rituals of each prospective pilgrim. Choliq in his research has explained that one of the things that determines the successful implementation of the Hajj rituals lies in the method used by the supervisor.

The delivery of ritual materials to the audience, especially those dominated by prospective elderly pilgrims, should be combined with several methods including: 
1. Affirmation and repetition on mandatory materials. Repetition can be practiced not only at one time but at some time until the Congregation really memorizes and understands the material. Understanding the material can be seen through evaluation at the end of each meeting. Repetition can be done through a light method leading to feeling to each congregations, so that they do not feel bored and the material can be kept easily in the their minds.

2. PAIKEM Active, Innovative, Creative, Effective and Fun learning. This method is usually used by mentors to make the participants more active in individuals and groups (Abdul, 2018: 40-41).

\section{Management}

Table. 4 Index on Planning Service Indicators

\begin{tabular}{llll}
\hline No & Statement & Index & Category \\
\hline 1 & $\begin{array}{l}\text { Ritual/manasik through } \\
\text { Schedule } \\
\text { announcements }\end{array}$ & 3.36 & $\begin{array}{l}\text { Very } \\
\text { Effective }\end{array}$ \\
2 & $\begin{array}{l}\text { Through media (email, } \\
\text { whatshapp, etc }\end{array}$ & Effective \\
3 & $\begin{array}{l}\text { Prepare early after } \\
\text { knowing the schedule } \\
\text { Total Index }\end{array}$ & 3.43 & $\begin{array}{l}\text { Very } \\
\text { Effective } \\
\text { Very } \\
\text { Effective }\end{array}$ \\
\hline
\end{tabular}

Planning indicator, although categorized index is very effective, is 3.32 . The media for announcing information through the website and other social media get an effective categorized index value of 3.16, because the answer from respondents " less agree" is $(9.6 \%)$.

Meantime, the other two statements are categorized as very effective. This means that efforts to find out the Hajj rit ual guidance schedule through social media such as Whatsapp and official emails from the Ministry of Religion, have not been fully responded to properly by respondents, although this is considered effective in providing information to each prospective pilgrim.

However, the data above shows that the planning service has been implemented well and is open to all prospective pilgrims. Planning for the implementation of the Hajj rituals is also informed early both manually (through announcements at the Office of
Religious Affairs or the Ministry of Religious Affairs) and through social media, so prospective pilgrims can prepare all the needs in the implementation of the Hajj rituals early.

Table. 5: Index on Implementation Services Indicator

\begin{tabular}{|c|c|c|c|}
\hline No & Statement & Index & Category \\
\hline 1 & $\begin{array}{l}\text { The number of guidance } \\
\text { participants is } 20\end{array}$ & 3.05 & Effective \\
\hline 2 & $\begin{array}{l}\text { The time for conducting } \\
\text { guidance is sufficient to } \\
\text { understand the rituals }\end{array}$ & 3.17 & Effective \\
\hline 3 & $\begin{array}{l}2 \text { meetings for guidance in } \\
\text { the Ministry of Religion }\end{array}$ & 3.13 & Effective \\
\hline 4 & $\begin{array}{l}8 \text { meetings for guidance in } \\
\text { the Office of Religious } \\
\text { Affairs }\end{array}$ & 3.24 & Effective \\
\hline 5 & $\begin{array}{l}\text { Implementation of guidance } \\
\text { for } 10 \text { days in a row }\end{array}$ & 3.07 & Effective \\
\hline 6 & $\begin{array}{l}\text { Understanding guidance } \\
\text { material for } 10 \text { days in a row }\end{array}$ & 3.15 & Effective \\
\hline 7 & $\begin{array}{l}\text { Guidance with other } \\
\text { congregations }\end{array}$ & 3.10 & Effective \\
\hline 8 & Material is delivered in turn & 3.35 & $\begin{array}{l}\text { Very } \\
\text { Effective }\end{array}$ \\
\hline 9 & $\begin{array}{l}\text { Accompanied during the } \\
\text { practice of rituals }\end{array}$ & 3.39 & $\begin{array}{l}\text { Very } \\
\text { Effective }\end{array}$ \\
\hline 10 & $\begin{array}{l}\text { Opportunity to ask questions } \\
\text { for participants }\end{array}$ & 3.42 & $\begin{array}{l}\text { Very } \\
\text { Effective }\end{array}$ \\
\hline 11 & $\begin{array}{l}\text { The material is reexplained } \\
\text { again if not understood yet }\end{array}$ & 3.46 & $\begin{array}{l}\text { Very } \\
\text { Effective }\end{array}$ \\
\hline 12 & $\begin{array}{l}\text { Participants are given the } \\
\text { opportunity to practice } \\
\text { worship }\end{array}$ & 3.36 & $\begin{array}{l}\text { Very } \\
\text { Effective }\end{array}$ \\
\hline \multirow[t]{2}{*}{13} & $\begin{array}{l}\text { Participants can practice } \\
\text { ihram clothes }\end{array}$ & 3.46 & $\begin{array}{l}\text { Very } \\
\text { Effective }\end{array}$ \\
\hline & Total Index & 3.26 & $\begin{array}{l}\text { Very } \\
\text { Effective }\end{array}$ \\
\hline
\end{tabular}

The data above shows that of the indicator for Hajj ritual guidance implementation service, thirteen items are submitted, seven of which were categorized as effective. This has influenced the acquisition of the index. Although categorized as very effective, the index value has decreased compared to the other five indicators.

The lowest score of the statement is the number of guidance participants is 20 with an index of 3.05. The other points also have slightly decreased value, namely the implementation of guidance conducted in a row (10 times) with index 3.07, the implementation of guidance with other congregations; 3.10, understanding the material for 10 consecutive days: 3.15 , the implementation of the guidance in the Ministry of Religion in 2 meetings with index 3.13 , the time of the implementation of the guidance is considered insufficient to understand the rituals of Hajj; 3.17 and guidance by the Office of Religious Affairs 8 times (days) of 3.24 . 
In this indicator, several questions were answered "less agree" from respondents, including guidance participants (11.4\%), implementation of guidance $(7.0 \%)$, guidance from religious Affairs office (7.0\%), carried out for 10 times / days (7.8\%), manasik understanding conducted for succession $(10.4 \%)$ and the incorporation of guidance from other districts (11.7\%).

Hajj Manasik guidance participants in giving answers tended to be quite varied. Regarding the number of participants, some respondents agreed if the number of participants was small or limited between 1120 people, in order to get easier to understand, instead of a large number of participants. On the other hand, some respondents also wanted a large number of guidance participants, especially prospective elderly pilgrims, because they could ask other participants.

The guidance was considered very short and was carried out consecutively, resulting in a number of prospective pilgrims unable to attend the guidance either by the Ministry of Religion or the Office of Religious Affairs, so they chose other alternatives by following guidance in the Hajj Guidance Group and through teachers / ustadz who had deeper knowledge about Hajj/ pilgrimage for the better Hajj rituals understanding.

The guidance was conducted in succession. In practice, some prospective pilgrims did not attend the full guidance, due to various reasons such as doing activities for 8 even 10 days in a row, especially those who worked as civil servants and employees. Therefore, the implementation of guidance on Hajj rituals should be done flexibly.

Hajj ritual guidance was conducted 10 times, including from the Ministry of Religion City / Regency 2 times and the Office of Religious Affairs 8 times lasting 4 hours for each material, face-to-face coupled with practice or simulation, question and answer, video playback or narration of the experience of the supervisor. Some prospective pilgrims considered it very short to understand the material delivered by the supervisors because the knowledge capacity of each candidate was different.
Indonesian Hajj Supervision

Commission (KBIH), Syamsu Ma'arif explained that in addition to hotel preparation services, transportation, consumption and others, to provide guidance on Hajj rituals to prospective pilgrims was another important task. However, it seems that year by year the guidance of Hajj rituals is just ordinary, in which Hajj is worship. He also stressed that the Ministry of Religion should pay particular attention to the guidance of the Hajj rituals, and it is better to find a new format in the guidance of good Hajj rituals so that prospective Indonesian pilgrims can be independent when performing the Hajj. He also added that from previous experience, guidance on Hajj rituals was often late because the implementation was not carried out from the beginning, as well as always decreasing the amount of guidance, ranging from 15 times to 8 times, and to the top of the guidance of rituals should have been given sufficient portions, so that candidates pilgrims had to really understand and be independent so that they no longer depended on others (republika, Friday, 25 October 2018).

Above all, the Ministry of Religion has tried improve quality in meeting the needs of Hajj rituals for every prospective pilgrims. However, in reality the guidance of Hajj rituals is still not finished, so it requires a new format, in order to provide more effective services and significantly be able to increase understanding and knowledge for every prospective pilgrims, especially Hajj fiqh not only in theory. Most importantly, the practice can be performed well when they are in the Holy Land.

\section{Program}

The whole points of the statement derived from the indicators of Hajj ritual guidance are in the categorized index of very effective, although some of the achievements have fluctuated. The index which is considered to be slightly decreased is the prohibition on killing animals during Ihram with an index of 3.30. Meanhile, the highest value is on the item of Hajj travel material with an index of 3.42. The achievement of the index on the indicator of guidance material 
shows that the guidance material on Hajj rituals including pillars, mandatory, and prohibitions during Ihram can be understood properly and can be implemented in the Holy Land.

Table. 7

Index to the Indicator of Hajj Ritual Guidance Material

\begin{tabular}{|c|c|c|c|}
\hline No & Statement & Index & Category \\
\hline 1 & Hajj travel material & 3.42 & $\begin{array}{l}\text { Very } \\
\text { Effective }\end{array}$ \\
\hline 2 & $\begin{array}{l}\text { Hajj provisions and } \\
\text { wisdom material }\end{array}$ & 3.35 & $\begin{array}{l}\text { Very } \\
\text { Effective }\end{array}$ \\
\hline 3 & $\begin{array}{l}\text { Use of toilets and } \\
\text { elevators }\end{array}$ & 3.35 & $\begin{array}{l}\text { Very } \\
\text { Effective }\end{array}$ \\
\hline 4 & Tayammum practice & 3.40 & $\begin{array}{l}\text { Very } \\
\text { Effective }\end{array}$ \\
\hline 5 & Ihram prayer & 3.40 & $\begin{array}{l}\text { Very } \\
\text { Effective }\end{array}$ \\
\hline 6 & Thawaf implementation & 3.39 & $\begin{array}{l}\text { Very } \\
\text { Effective }\end{array}$ \\
\hline 7 & Sai procedure & 3.39 & $\begin{array}{l}\text { Very } \\
\text { Effective }\end{array}$ \\
\hline 8 & $\begin{array}{l}\text { Wukuf (before staying) } \\
\text { at Arafah }\end{array}$ & 3.39 & $\begin{array}{l}\text { Very } \\
\text { Effective }\end{array}$ \\
\hline 9 & Tahallul & 3.38 & $\begin{array}{l}\text { Very } \\
\text { Effective }\end{array}$ \\
\hline 10 & Hajj order & 3.38 & $\begin{array}{l}\text { Very } \\
\text { Effective }\end{array}$ \\
\hline 11 & $\begin{array}{l}\text { Implementation of } \\
\text { ihram and miqat makani }\end{array}$ & 3.35 & $\begin{array}{l}\text { Very } \\
\text { Effective }\end{array}$ \\
\hline 12 & $\begin{array}{l}\text { Implementation } \\
\text { mabit in Musdalifah }\end{array}$ & 3.36 & $\begin{array}{l}\text { Very } \\
\text { Effective }\end{array}$ \\
\hline 13 & Throwing jamarah & 3.34 & $\begin{array}{l}\text { Very } \\
\text { Effective }\end{array}$ \\
\hline 14 & Mabit in Mina & 3.35 & $\begin{array}{l}\text { Very } \\
\text { Effective }\end{array}$ \\
\hline 15 & $\begin{array}{l}\text { Implementation of } \\
\text { jumrah ula, wustha and } \\
\text { aqabah }\end{array}$ & 3.31 & $\begin{array}{l}\text { Very } \\
\text { Effective }\end{array}$ \\
\hline 16 & Thawaf wada & 3.39 & $\begin{array}{l}\text { Very } \\
\text { Effective }\end{array}$ \\
\hline 17 & $\begin{array}{l}\text { Prohibition during } \\
\text { ihram }\end{array}$ & 3.38 & $\begin{array}{l}\text { Very } \\
\text { Effective }\end{array}$ \\
\hline 18 & Actions that breaks Hajj & 3.39 & $\begin{array}{l}\text { Very } \\
\text { Effective }\end{array}$ \\
\hline 19 & $\begin{array}{l}\text { Do not wear tailor made } \\
\text { and fragrance }\end{array}$ & 3.39 & $\begin{array}{l}\text { Very } \\
\text { Effective }\end{array}$ \\
\hline 20 & $\begin{array}{l}\text { Prohibition of killing } \\
\text { animals }\end{array}$ & 3.30 & $\begin{array}{l}\text { Very } \\
\text { Effective }\end{array}$ \\
\hline 21 & $\begin{array}{l}\text { Marriage contract, and } \\
\text { arguing during Ihram }\end{array}$ & 3.43 & $\begin{array}{l}\text { Very } \\
\text { Effective }\end{array}$ \\
\hline 22 & Pilgrimage object & 3.34 & $\begin{array}{l}\text { Very } \\
\text { Effective }\end{array}$ \\
\hline & Indeks Total & 3.37 & $\begin{array}{l}\text { Very } \\
\text { Effective }\end{array}$ \\
\hline
\end{tabular}

Program indicator (Hajj ritual guidance materials) is at index 3.37 or categorized as very effective. The index achievement cannot be separated from the guidance attended by every pilgrim. In addition to guidance in the Office of Religious Affairs and the Ministry of Religion as mandatory guidance for all pilgrims, there is also other guidance attended by every prospective pilgrim including pre-rituals, $\mathrm{KBIH}$ guidance, and guidance through teachers / ustadz, as an effort to increase the understanding of Hajj rituals for prospective pilgrims.

Pre Manasik/ritual is a form of guidance conducted by the Ministry of Religion through partnerships to provide basic teaching to prospective pilgrims to obtain the title of hajj Mabrur, as well as debriefing in terms of good physical and mental readiness. Pre-ritual implementation, has not become a mandatory program for the Ministry of Religion of the City / District, but only an initiative and creativity of each Hajj organizer in the area of the level of the Ministry of Religion of the city / district and the Office of Religious Affairs carried out by extension workers.Iin addition, pre-rituals were also performed by Indonesian Hajj Supervision Commission (KBIH).

Likewise, pre manasik conducted by $\mathrm{KBIH}$ was guidance material relating to studies and debriefing of physical and mental readiness as what had been done in several Ministry of Religion such as Tarakan City in collaboration with the Indonesian Hajj Fraternity Association (IPHI) to provide debriefing to each prospective pilgrimage through independent ritual activities.

Additionally, some guidance attended by each prospective pilgrim as alternative choices to gain knowledge about intensive Hajj rituals included guidance from $\mathrm{KBIH}$ and teachers. Based on data collected, the tendency of respondents to attend guidance in $\mathrm{KBIH}$ and teachers was still lacking or only around 20 percent.

\section{Facilities and Infrastructure}

Indicator of facilities and infrastructure was intended to determine the assessment of prospective pilgrims to the facilities and infrastructure prepared and used by the ministry of religion in the implementation of Hajj rit ual guidance both at the level of the Ministry of Religious Affairs and the Office of Religious Affairs. Of the 8 statements issued, one was on the comfort of the implementation of the ritual guidance in the Hall of the Office of Religious Affairs, even though the index is 3.26 or categorized as very high, it is lower than the achievement value in other items. 
Table. 8

Index to Indicator of Facilities and Infrastructure

\begin{tabular}{|c|c|c|c|}
\hline No & Statement & Index & Category \\
\hline 1 & $\begin{array}{l}\text { Good media } \\
\text { system) }\end{array}$ & 3.38 & $\begin{array}{l}\text { Very } \\
\text { Effective }\end{array}$ \\
\hline 2 & Using LCD & 3.33 & $\begin{array}{l}\text { Very } \\
\text { Effective }\end{array}$ \\
\hline 3 & Manasik guidance books & 3.37 & $\begin{array}{l}\text { Very } \\
\text { Effective }\end{array}$ \\
\hline 4 & Comfort in the KUA Hall & 3.26 & $\begin{array}{l}\text { Very } \\
\text { Effective }\end{array}$ \\
\hline 5 & $\begin{array}{l}\text { Comfort in the Hall of } \\
\text { Ministry of Religion }\end{array}$ & 3.32 & $\begin{array}{l}\text { Very } \\
\text { Effective }\end{array}$ \\
\hline 6 & $\begin{array}{l}\text { Comfort in Mosque Hall, } \\
\text { others }\end{array}$ & 3.34 & $\begin{array}{l}\text { Very } \\
\text { Effective }\end{array}$ \\
\hline 7 & $\begin{array}{l}\text { Presentation of material } \\
\text { using a combination of } \\
\text { lecture and simulation }\end{array}$ & 3.34 & $\begin{array}{l}\text { Very } \\
\text { Effective }\end{array}$ \\
\hline 8 & $\begin{array}{l}\text { Using props: miniature } \\
\text { Ka'bah, ihram clothes } \\
\text { and others }\end{array}$ & 3.44 & $\begin{array}{l}\text { Very } \\
\text { Effective }\end{array}$ \\
\hline & Total Index & 3.34 & $\begin{array}{l}\text { Very } \\
\text { Effective }\end{array}$ \\
\hline
\end{tabular}

The implementation of Hajj Manasik Guidance in the Hall of the Office of Religious Affairs is considered not optimal due to inadequate support of facilities and infrastructure, such as the capacity of the room to accommodate Hajj Manasik guidance participants, especially districts that have a large number of prospective pilgrims. Besides,, the lack of other facilities includes LCD, sound system, large yard for the practice of thawaf, and other facilities and infrastructure. As a result, the implementation of the rituals of Hajj was mostly performed in hotels, mosques, embarkations, and local government halls.

\section{Analysis of Index Findings 3.55}

The acquisition of the Hajj ritual guidance services at the Ministry of Religion in Eastern Indonesia is : 3.55 or categorized as "Very Effective". This shows that the government, in this case the Ministry of Religion and specifically the District Office of Religious Affairs, has performed its functions properly. The program considered to support the implementation of the rituals of Hajj is pre manasik to provide knowledge of early Hajj rituals to each prospective pilgrim conducted by Islamic religious instructors on an ongoing basis, even though not all the Office of Religious Affairs apply it. In addition, it shows that the Ministry of Religion has cooperated with other relevant parties in an effort to provide better Hajj ritual services.

The principle of public service as stipulated in the Regulation of Ministry of Administrative and Bureaucratic Reform No. 63 of 2003 shows that the Ministry of Religion and the Office of Religious Affairs in the District have provided Hajj ritual services to each prospective pilgrim in accordance with the principles in question. Hajj ritual services have been carried out in a transparent and open manner starting with the announcement of the depart ure, the schedule of Hajj rituals, Hajj rituals, etc., openly and easily accessed through social media, or manually.

In view of accountability, the services provided to each prospective pilgrim is in accordance with the procedures and legislation or rules that are applicable. Hajj ritual services are also carried out in accordance with the conditions of service providers, in this case the Ministry of Religious Affairs and the Office of Religious Affairs of the District to each prospective pilgrim, so it is more effective and efficient.

Mentors such as kiai and ustad were involved as every prospective pilgrim expected because they had knowledge and experience of the pilgrimage, so prospective pilgrimages got extraordinary enthusiasm to attend the guidance of Hajj rituals. In addition, guidance on Hajj rituals was carried out without discriminatory treatment between one another, and services were carried out by prioritizing the rights and obligations of both service providers and service recipients.

Achievement index 3.55, or categorized as "Very Effective", explains that the Hajj ritual services performed by the Ministry of Religion/KUA have fulfilled the needs of prospective pilgrims. Among the most important of fulfilling these needs is an adequate understanding of the prospective pilgrims to the pillars, mandatory, Sunnah and the restrictions on Hajj.

Thus, the Ministry of Religion must maintain this highly effective service, while improving the service process deemed lacking, Matters that need to be improved are primarily; insufficient time for guidance, preparation of facilities and infrastructure at 
KUA, and reconstruction of regulations to meet the needs of prospective pilgrims. The consistency of the Ministry of Religion to maintain effective Hajj ritual services is expected to give satisfaction to prospective pilgrims in the following years.

\section{CLOSING}

Hajj/pilgrimage ritual guidance service, with an index of 3.55 , shows that the Ministry of Religion of the City/District, and specifically the Office of Religious Affairs of the District has carried out their duties and functions properly as the front guard in providing services to the community. The services provided always refer to the principles of public service, including transparency, accountability, conditionality, participatory, equality of rights and balance of rights and obligations to create the services with very effective results.

Dealing with the effectiveness level of Hajj ritual services based on dimension (4) derived from 6 variables and 52 statement items, a total index obtained is 3.55. The index is based on the indicators namely: committee services: 3.54 (very effective), advisory services; 3.43 (very effective), planning services: 3.32 (very effective), implementation services: 3.26 (very effective), guidance material: 3.37 (very effective), and facilities and infrastructure: 3.35 (very effective).

The index obtained per city/locatio is city: Balikpapan: 3.72 (very effective), Tarakan: 3.51 (very effective), Palopo: 3.74 (very effective), Parepare: 3.72 (very effective), Ternate: 3.31 (very effective), Tidore: 3.45 (very effective), Gorontalo: 3.67 (very effective), Kotamubagu: 3.93 (very effective), Kendari: 3.60 (very effective), Baubau: 3.30 (very effective), Ambon: 3.49 (very effective), Tual: 3.46 (very effective), Jayapura: 3.44 (very effective), and Makassar: 3.45 (very effective).

\section{ACKNOWLEDGEMENT}

The study of "The Effectiveness of Pilgrimage/Hajj Ritual Guidance Services at the Ministry of Religion in Eastern Indonesia" could be conducted due to funding support from the Religious Research and
Development Agency DIPA Makassar 2018. We would like to thank all of the parties who have supported the implementation of this study. Special thans to Mr. Prof Dr.H.Abd Kadir Ahmad us supervisor in this study and special thanks to the manager of Al-Qalam Journal for accepting and publishing this article.

\section{BIBLIOGRAPHY}

Abdul, C. 2018. Esensi Program Bimbel Manasik Haji Upaya Pemberdayaan Masyarakat. At-Taqaddum, 10(1), 2349.

Arafah. Sitti. 2017. Pelayanan Kementerian Agama Terhadap Umat Minoritas di Kota Palu. Penamas: Jurnal Penelitian Agama Dan Masyarakat, 31(1).

Departemen Pendidikan Nasional. 2003.

Kamus Besar Bahasa Indonesia. Jakarta.

Dirjen Pelaksana Haji dan Umrah. Pelaksanaan Bimbingan Manasik Haji Tingkat Kabupaten/Kota dan Kantor Urusan Agama serta Pembekalan Beregu dan Berkelompok 2018. Indonesia.

Fahham. Achmad Muchaddam. 2015. Penyelenggaraan Ibadah Haji: Masalah dan Penanganannya. Kajian, 20(3).

HAM, M. H. dan. Penyelenggaraan Ibadah Haji 2008. Republik Indonesia.

Indonesia, U.-U. R. Pelayanan Publik 2009.

Kawu, Abdul Shadiq, Dkk. 2013. Pelayanan Haji dalam Sorotan Publik. Makassar: Hasanuddin Uneversity Press.

Kementerian Agama. PMA No. 34 tahun 2016 tentag Organisasi dan Tata Kerja Kantor Urusan Agama Kecamatan 2016.

Koeswinarno, dkk. 2014. Efektivitas Kelompok Bimbingan Ibadah Haji Dalam Memberikan Pelayanan dan Bimbingan Terhadap Jamaah Haji. (Koeswinarno, Ed.). Jakarta: Badan Litbang dan Diklat Kemenag RI Puslitbang Kehidupan Keagamaan.

Menteri Agama. Penyelenggaraan Ibadah Haji Reguler 2012. Indonesia.

Menteri Agama. Bimbingan Manasik Haji bagi Jemaah Haji oleh Kantor Urusan Agama Kecamatan. 2014. Indonesia. 
Menteri Pendayagunaan Aparatur Negara. Pedoman Umum Penyelenggaraan Pelayanan Publik. 2003.

Muin. Abd. 2014. Efektifitas Pembinaan Madrasah Diniyah di Kota Yogyakarta dalam Jurnal; Edukasi, Volume 12 Nomr 3 Desember 2014.

Nurul, B. 2014. Haji. Retrieved from www.itjen.kemenag.go.id

Pajala, K. 2005. Pengaruh Bimbingan Manasik Haji Terhadap Peningkatan Kualitas Ibadah Haji di Kota Palu Sulawesi Tengah. UIN Alauddin Makassar.

Suharsimi, A. 2007. Dasar-Dasar Evaluasi Pendidikan. Jakarta: Bumi Aksara.
Suparta, Munzeir. 2014. Penyelenggaraan Haji dalam Perspektif Pengawasan. Retrieved from www.itjen.kemenag.go.id

Syamsurijal. 2017. Ajji Ugie: Monografi Sosial Budaya Jemaah Haji di Segeri Pangkep Sulawesi Selatan. Makassar.

Umrah, D. J. P. H. dan. Pedoman Pelaksanaan Bimbingan Manasik Haji oleh Kantor Kementerian Agama Kabupaten/Kota dan Kantor Urusan Agama Kecamatan (2017). Indonesia.

Widyarini. 2013. Manajemen Kelompok Bimbingan Ibadah Haji ( KBIH ). Jurnal Ekonomi Dan Bisnis Islam, EKSIBISI, VII(2), 164-185.

Yunus, M. 1994. Kamus Arab Indonesia. Jakarta: Bumi Aksara. 